\title{
Evenmatched FCAW Process in API 5L X80 Steel Welded Joint
}

\author{
Adérito de Aquino Filho ${ }^{\mathrm{a}, \mathrm{b} *}$, Yogendra Prasad Yadava ${ }^{\mathrm{a}}$, Ricardo Artur Sanguinetti Ferreira \\ aDepartamento de Engenharia Mecânica, Universidade Federal de Pernambuco - UFPE, \\ Av. Ac. Hélio Ramos, s/n, Cidade Universitária, CEP 50740-530, Recife, PE, Brasil \\ ${ }^{\mathrm{b}}$ Escola Politécnica - POLI, Universidade de Pernambuco - UPE, \\ Rua Benfica, 445, Madalena, CEP 50750-470, Recife, PE, Brasil
}

Received: October 4, 2012; Revised: October 25, 2013

\begin{abstract}
The evenmatched welding conditions in FCAW-G process were used in API 5L X80 steel. In this study, two joint geometries (bevel $25^{\circ}$ and $35^{\circ}$ ) with different process parameters were used. Each type of joint was welded with one type of consumable: AWS E81T1-Ni1C (evenmatched), with variation of heat input. During welding the voltage and current varied in a range, in order to preserve the transfer mode by short circuit. For each welded joint, it was studied the influence of these welding parameters in the weld metal's quality and, the influence of the bevel angle in the extent of heat affected zones and their correlated mechanical properties. The microstructures were characterized by optical and scanning microscopy, in which the qualitative analyses of microconstituents were performed in transverse sections of weld bead. The mechanical properties for each condition were obtained by uniaxial tensile, hardness, impact and bending tests, allowing the comparison between the different parameters. The tensile test results obtained with a smaller bezel angle had mechanical resistance slightly higher than those of bigger angle joint. Consumables with the same mechanical strength of the base metal (evenmatched) presented performances consistent with their levels of resistance and proved to be viable, depending on the application.
\end{abstract}

Keywords: FCAW process, evenmatched welding, API 5L X80 steel

\section{Introduction}

The welding processes used in API 5L steels have been conservative. In this same vein Hillenbrand et al. ${ }^{1}$, cite two welding procedures for steel X80, developed together by Ruhrgas AG / Mannesmann Anlagenbau with European manufacturers of consumables: welding in vertical down by SMAW (manually), and by GMAW (automatically) for all positions.

Following Quintana and Johnson ${ }^{2}$, the fabrication of a welded joint using a single consumable is neither practical nor low cost. For example, many in line pipelines are produced using both SMAW for root pass and FCAW-S for filler passes. The manufacture of large compositions or structures normally involves welding using both GMAW and FCAW-G processes in industries, or SMAW and FCAW-S processes in the field. The welding processes of tacking and adjustment are usually made by SMAW, and finalized with other welding processes to achieve higher deposition rates. These examples of applications illustrate that mixtures of different weld metals can occur in a single joint. These patterns indicate that a mixture of different filler materials and process occurs frequently as a normal part of the manufacturing process. In contrast, many welding consumables are optimized without considering underlying dilution effects to the base metal or the different chemical compositions of the weld metal.

*e-mail: aderito.aquino@yahoo.com.br
It is usual to classify the welds as overmatched, evenmatched or undermatched, if the value of yield strength or ultimate stress of the WM is respectively superior, equal or inferior to the WM. Overmatched welding is commonly used in structural components under stress (AWS D1.1 ${ }^{[3]}$ ). Undermatched welding is sometimes used in structural joints of high strength steel in order to minimize the tendency to hydrogen-induced cracking in welded metal, reducing or preventing additional cost of preheating

Graf and Niedorhoff $\mathrm{f}^{4}$ analyzed the performance of overmatched and undermatched welds in testing plates. Their results suggested that it is acceptable to make welding with AWS E 9010-G cellulosic electrodes in X70 degree, and in some cases in grade X80. This results show this method is suitable for API 5L X80 steel.

In a review, Loureiro ${ }^{5}$ showed that welding joints (WJ) are naturally heterogeneous materials, exhibiting variations in the microstructures and mechanical properties (hardness, strength and toughness) through the welding metal (WM) and heat affected zone (HAZ). A phenomenon of mixing with different weld metals and dilution, and complex thermal cycles in HAZ can produce different microstructures (Quintana and Johnson ${ }^{2}$, Loureiro and Fernandes ${ }^{6}$ ). WJ performance seems to depend on the size and level of disagreement on the strength and toughness of each area of the WJ (Toyoda et al. ${ }^{7}$ ). 
According to Utterberg and Svensson ${ }^{8}$, the increase of nickel content in rutile wires associated with increased toughness can be explained by the grain refinement. For Evans $^{9}$ the increase of nickel content in the weld metal decreases the amount of primary ferrite, in other words, there is a reduction of ferrite veins preponderating an increase of acicular ferrite volume over ferrite of second phase. Vieira ${ }^{10}$ in his evaluation on the toughness of the weld metal with AWS 81T1-Ni1 wire, according to ASME A 5.29 and PETROBRAS N-189 standards, using voltages around $27 \mathrm{~V}$ to $28 \mathrm{~V}$, current about $188 \mathrm{~A}$ to $270 \mathrm{~A}$, and welding speeds between $3.67 \mathrm{~mm} / \mathrm{s}$ to $6.35 \mathrm{~mm} / \mathrm{s}$, obtained acicular ferrite microstructure in columnar regions.

In this study, the quality of evenmatched FCAW-G procedures were evaluated through the correlation microstructure/mechanical properties of welded joints in API 5L X80 steel. It is emphasized in welding procedures that they were carried out entirely with a single type of evenmatched consumable (AWS E81T1-Ni1C).

\section{Material and Methods}

The base metal used in this study was API 5L X80 pipeline steel, conformed by the UOE process, with a nominal diameter of $864 \mathrm{~mm}$ (34 "), thickness of $19 \mathrm{~mm}$. During steel manufacturing the sheets were produced by controlled rolling without accelerated cooling (TMCP - thermomechanical controlled process). The chemical compositions of steel and mechanical properties are presented in Tables 1 and 2 respectively. Using the equations as recommended by the International Institute of Welding (IIW) and by the standard API 5L ${ }^{[11]}$, the values (modified cracking parameter) $\mathrm{PCM}=0.15$ and (equivalent carbon) $\mathrm{CE}=0.40$ were obtained, taking as basis the chemical composition of the base material as shown in Table 1 .
The consumable wire used in this study was E81T1Ni1C (evenmatched), with diameter of $1.2 \mathrm{~mm}$ for the FCAW-G processes following A5.29 (AWS SFA-5.29 ${ }^{[13]}$ ) standard.

According to the information stated in the Quality Certificate, dated from 06.10.2009, issued by the manufacturer, the E81T1-Ni1C consumable belongs to VT924T4658. Table 3 presents the chemical composition of consumable. In the same way, the mechanical properties of tubular wire as welded are shown in Table 4.

\subsection{Welding procedure}

Specimens for welding were cut of the pipeline in longitudinal direction. According to the manufacturer's recommendations, the most appropriate joint geometry has the following measures: thickness of $19 \mathrm{~mm}$, nose height of $1.5 \mathrm{~mm}$ to $2.0 \mathrm{~mm}$ and nose opening $2.0 \mathrm{~mm}$ to $2.5 \mathrm{~mm}$ for a bezel angle of $35^{\circ}$. In order to reduce the utilization of consumables, a bezel angle of $25^{\circ}$ was experienced. Figure 1 illustrates the schematic joints geometry.

Table 5 presents the welding procedures specifications for the FCAW-G process. In these specifications, some changes in welding parameters were produced considering the groove geometry, welding current and voltage of arc. Even with these changes, the welding parameters were used within the ranges recommended by the manufacturers of consumable electrodes, in accordance with the ASMEIX $^{[14]}$ standard.

Usually, current intervals and welding speed, both with long extension, are utilized in welding procedure to avoid the base metal to be pierced by a wire in the bevel nose. The reason is that the values used in these parameters in the root and hot passes are too low.

The temperature between passes has the objective of minimizing the tendency to hydrogen-induced cracking in welded metal. Maximum interpass temperature of $150{ }^{\circ} \mathrm{C}$ followed wire's manufacturer instructions.

Table 1. Chemical composition of the base metal, according to manufacturer (API $5 \mathrm{~L}^{[11]}$ ).

\begin{tabular}{cccccccc}
\hline \multicolumn{7}{c}{ Chemical elements (wt \%) } \\
\hline $\mathbf{C}$ & $\mathbf{S}$ & $\mathbf{N}$ & $\mathbf{A l}$ & $\mathbf{S i}$ & $\mathbf{P}$ & $\mathbf{T i}$ & $\mathbf{V}$ \\
\hline 0.03 & 0.003 & 0.0056 & 0.030 & 0.17 a 1.24 & 0.013 & 0.017 & 0.025 \\
\hline $\mathbf{C r}$ & $\mathbf{M n}$ & $\mathbf{N i}$ & $\mathbf{C u}$ & $\mathbf{N b}$ & $\mathbf{M o}$ & $\mathbf{B}$ & $\mathbf{C a}$ \\
\hline 0.158 & 1.75 & 0.013 & 0.010 & 0.072 & 0.187 & 0.0001 & 0.0024 \\
\hline
\end{tabular}

Table 2. Mechanical properties of determined base metal (ASTM A $370^{[12]}$ ).

\begin{tabular}{ccc}
\hline $\begin{array}{c}\text { Yield Point }- \text { YE } \\
(\mathbf{M P a})\end{array}$ & $\begin{array}{c}\text { Tensile Strength }- \text { TS } \\
(\mathbf{M P a})\end{array}$ & $\begin{array}{c}\text { Elongation } \\
(\boldsymbol{\%})\end{array}$ \\
\hline 570 & 719 & 16.75 \\
\hline
\end{tabular}

Table 3. Chemical composition of weld metal as welded. (AWS A5.29 $9^{[13]}$ ).

\begin{tabular}{|c|c|c|c|c|c|c|c|c|c|c|}
\hline \multirow[t]{2}{*}{ Tubular wire } & \multicolumn{10}{|c|}{ Chemical elements (wt \%) } \\
\hline & $\mathbf{C}$ & Si & Mn & $\mathbf{P}$ & $\mathbf{S}$ & $\mathrm{Cr}$ & $\mathrm{Ni}$ & Mo & $\mathbf{V}$ & $\mathrm{Cu}$ \\
\hline E81T1-Ni1C (AWS A 5.29) & 0.12 & 0.80 & 1.50 & 0.03 & 0.03 & 0.15 & $0.80-1.10$ & 0.35 & 0.05 & 0.12 \\
\hline
\end{tabular}


Table 4. Mechanical properties of tubular wire in the condition as welded (AWS A5.29 ${ }^{[13]}$ ).

\begin{tabular}{lcccccc}
\hline Tubular wire & Specification & $\begin{array}{c}\text { Yield Strength - YE } \\
(\mathbf{M P a})\end{array}$ & $\begin{array}{c}\text { Tensile Strength }-\mathbf{T S} \\
(\mathbf{M P a})\end{array}$ & $\begin{array}{c}\text { Elongation } \\
(\boldsymbol{\%})\end{array}$ & $\begin{array}{c}\text { Temperature } \\
\left({ }^{\circ} \mathbf{C}\right)\end{array}$ & $\begin{array}{c}\text { Charpy V } \\
(\mathbf{J})\end{array}$ \\
\hline E81T-Ni1 C & AWS A5.29 & 470 & $550-690$ & 19 & -30 & 27 \\
\hline
\end{tabular}

Table 5. Specification for Welding Procedure FCAW-G (ASME IX $\left.{ }^{[14]}\right)$.

\begin{tabular}{lcccc}
\hline \multicolumn{1}{c}{ Weld condition } & G-5 & G-6 & G-7 & G-8 \\
\hline Tubular wire & E 81T1- Ni 1C & E 81T1- Ni 1C & E 81T1- Ni 1C & E 81T1- Ni 1C \\
Bezel angle & $35^{\circ}$ & $35^{\circ}$ & $25^{\circ}$ & $25^{\circ}$ \\
Polarity & $\mathrm{CC}^{+}$ & $\mathrm{CC}^{+}$ & $\mathrm{CC}^{+}$ & $\mathrm{CC}^{+}$ \\
Current (A) & $120-180$ & $140-200$ & $120-180$ & $140-200$ \\
Voltage (V) & $26-28$ & $29-30$ & $26-28$ & $29-30$ \\
Shielding gas & $100 \% \mathrm{CO}_{2}$ & $100 \% \mathrm{CO}_{2}$ & $100 \% \mathrm{CO}_{2}$ & $100 \% \mathrm{CO}_{2}$ \\
Gas flow (1/ min) & $16-22$ & $16-22$ & $16-22$ & $16-22$ \\
Wire speed (m / min) & $5-8$ & $5-10$ & $5-8$ & $5-10$ \\
Welding speed (mm / s) & $2-7$ & $2-7$ & $2-7$ & $2-7$ \\
Extension of wire (mm) & $6-19$ & $6-19$ & $6-19$ & $6-19$ \\
Welding position & flat & flat & $150{ }^{\circ} \mathrm{C}$ & flat \\
Maximum interpass temperature & $150{ }^{\circ} \mathrm{C}$ & $150{ }^{\circ} \mathrm{C}$ & $150{ }^{\circ} \mathrm{C}$ \\
\hline
\end{tabular}

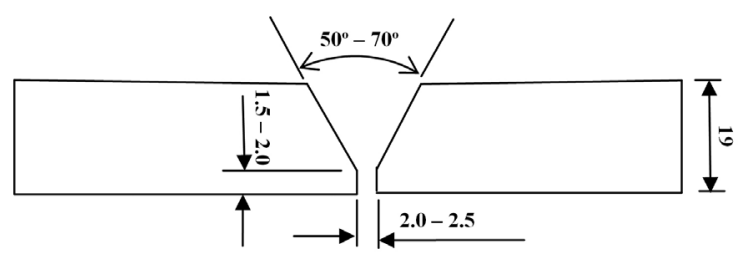

Figure 1. Schematic Joints Geometry with dimensions in $\mathrm{mm}$.

The temperatures among passes were obtained using an optical pyrometer with adjustable permittivity and accuracy about $0.1^{\circ} \mathrm{C}$. The stick out of the wire was measured with a metal tape measure with an accuracy of $1 \mathrm{~mm}$. The welding speed was estimated by measuring the time of each pass, divided by the traversed distance. The heat input $(\mathrm{H})$ was calculated on the basis of Equation 1. During welding, the thermal efficiency (of the process was considered as $\eta=0.80, \mathrm{~V}$ (welding voltage), I (welding current) and $\mathrm{v}$ (welding speed).

$\mathrm{H}=\eta \frac{\mathrm{V} . \mathrm{I} .}{\mathrm{V}}$

\subsection{Microstructural characterization}

The microestrutural characterization was performed after the traditional metallographic preparation, in which sandpapers with a granulometry of 220, 320, 400, 600 and 1000 mesh were used. After sanding, the surfaces were polished using diamond paste of $1 \mu \mathrm{m}$. After polishing, the samples were lightly etched with Nital $5 \%$ for a period of 5 seconds to 10 seconds. The macroscopic analyses were carried out in a stereoscope with magnification less than 10 times, and the microscopic analyses were realized by the optical microscopy and scanning electron microscopy (SEM).

The microstructural characterization was realized in one specimen of each different welding condition in the following regions: the base metal, the heat affected zone and fusion zone.

\subsection{Mechanical testing}

For each welding condition two test specimens with reduced cross-sections were prepared, according to ASME $\mathrm{IX}^{[14]}$. The specimens were tested in a uniaxial tensile machine with a crosshead speed of $1 \mathrm{~mm} / \mathrm{min}$, following the guidance of ASTM A370 [12].

For the bending test six specimens were drawn up for each welding condition. Each specimen had a transverse section of $10 \times 19 \mathrm{~mm}$, following ASME IX ${ }^{[14]}$, which underwent the bending guided tests pursuant to the positions: face, root and lateral transverses, holding one specimen for each face and root positions and four for lateral position. The bending was accomplished in a hydraulic press where the material was conformed plastically until the specimen reached 120 degrees or broke before then.

The same specimens used for microestrutural characterization were undergone to micro hardness test, following ASTM E384 ${ }^{[15]}$ standard. Micro hardness test had as parameters a load of 300 grams, indented time of 20 seconds and a print image magnification of 40 times. For each welding condition, the microhardness was taken in cross-section of the specimen, considering the central zone of the welded joint in which six points in each side of 0.5 $\mathrm{mm}$ distant from each other, and all them in line at $3 \mathrm{~mm}$ from the free surface.

The Charpy impact tests were performed in a machine enable to produce up to $300 \mathrm{~J}$ of impacts energy, according to ASTM A $370^{[12]}$ standard. Each welding condition was tested 
in $\mathrm{WM}$ and $\mathrm{HAZ}$ regions with temperatures between $0{ }^{\circ} \mathrm{C}$ e $25{ }^{\circ} \mathrm{C}$ (ambient). Three specimens were tested for each temperature. Under the temperature of $1{ }^{\circ} \mathrm{C}$, the specimens were kept in a brine bath at a temperature of around $\left(-10^{\circ} \mathrm{C}\right)$ for a time of 10 minutes. After this time, the specimens were removed from the brine and brought to the machine to wait the moment when the temperature reached $0{ }^{\circ} \mathrm{C} \pm 1{ }^{\circ} \mathrm{C}$. During the test, the temperature monitoring was carried out using a laser optical pyrometer with adjustable permittivity. For these tests, the specimens were machined and finished in which the notches were placed in two different regions: one in the weld metal and another in HAZ, as Figure 2 and 3.

\section{Results and Discussion}

\subsection{Welding performance}

The welding of each condition was followed up and described in welding monitoring reports and the used parameters are summarized in Table 6 . It was observed that the welding condition G-5 $\left(35^{\circ}\right)$ and G-7 $\left(25^{\circ}\right)$ demanded a smaller heat input, with average of $0.60 \mathrm{~kJ} / \mathrm{mm}$ for G-5 $\left(35^{\circ}\right)$ and $0.53 \mathrm{~kJ} / \mathrm{mm}$ for $\mathrm{G}-7\left(25^{\circ}\right)$, as having different Bisel geometry, were welded with smaller values of tension and current. The variation of welding speed among conditions was not significant to justify the substantial variations in the heat inputs. Although the welding parameters were maintained within the specified ranges (Table 5), the resultant variations justify changes in heat inputs for each condition.

In general, it can be observed that the welding time was shorter whenever the lower angle $\left(25^{\circ}\right)$ was used, regardless of heat input.

\subsection{Microstrutural characterization}

The microestrutural characterizations carried out by optical microscopy showed that, in this observation scale, the microstructures consists of ferritic grains slightly enriched with perlite in the contours. In Figure 4, condition G-8 $(0.68 \mathrm{~kJ} / \mathrm{mm})$, presents grain size about $10 \mu \mathrm{m}$, while in Figure 5, condition G-7 $(0.53 \mathrm{~kJ} / \mathrm{mm})$ shows smaller grain size, justified by the smaller heat input as compared with G-8 condition.

The condition G-7 and G-8, in this scale of observation already shows the tendency of producing acicular microconstituents in the weld metal as predicted by Evans 9 , although it was observed the majority of polygonal ferrite in the microstructure. The conditions G-7 and G-8, with average heat inputs of $0.63 \mathrm{~kJ} / \mathrm{mm}$ and $0.68 \mathrm{~kJ} / \mathrm{mm}$ respectively, its cooling condition was slower when compared to the one proposed by Vieira ${ }^{10}$. This result suggests that the

Table 6. Summary of monitoring welding conditions.

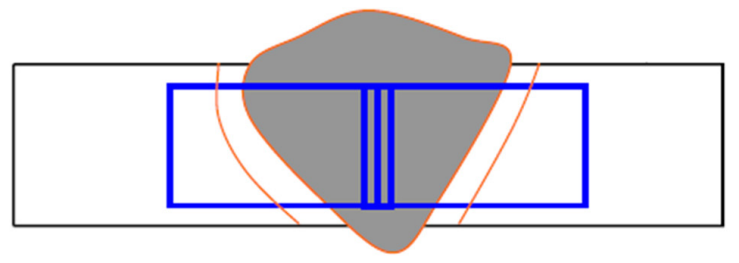

Figure 2. Schematic of test specimen of WM.

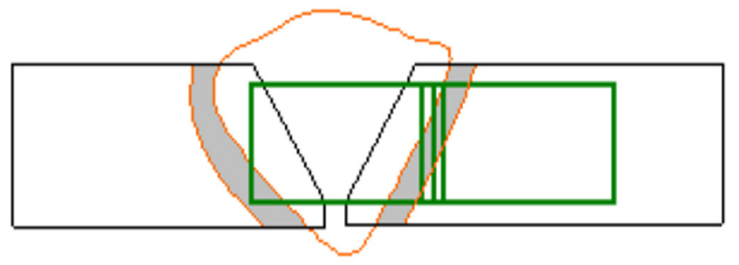

Figure 3. Schematic of test specimen of HAZ.

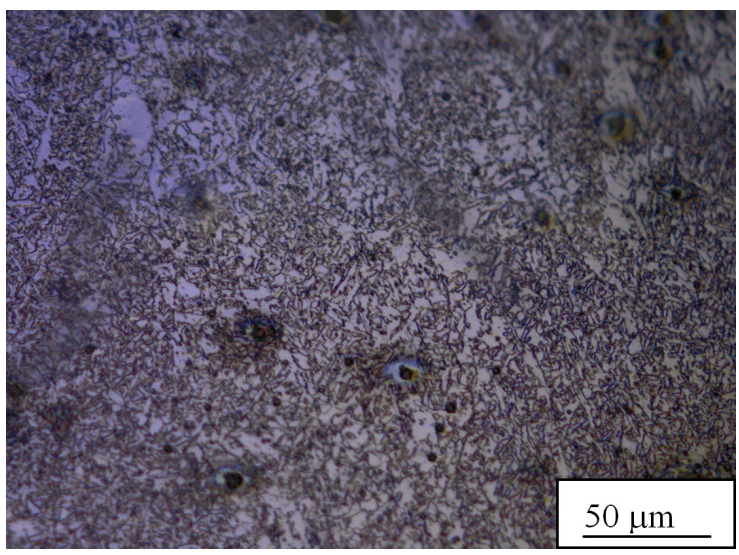

Figure 4. Microscture obtained in G-7's weld metal zone, showing the tendency of AF's presence.

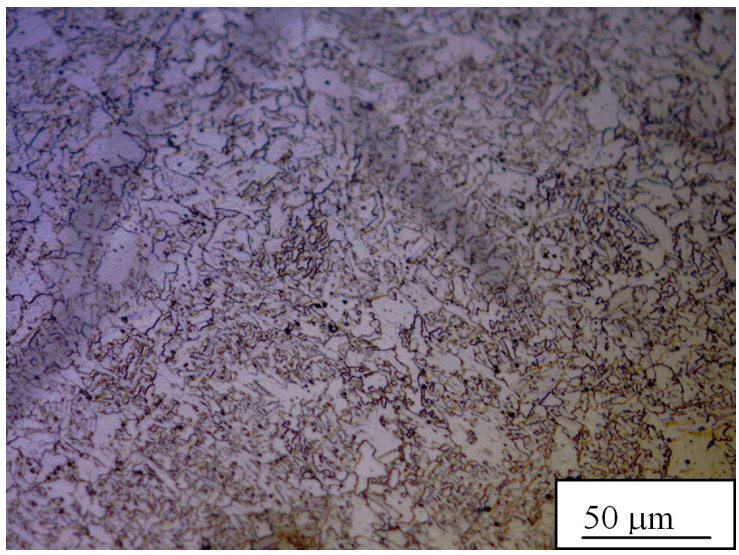

Figure 5. Microscture obtained in G-8's weld metal zone, showing the tendency of AF's presence.

\begin{tabular}{cccccc}
\hline $\begin{array}{c}\text { Welding } \\
\text { condition }\end{array}$ & $\begin{array}{c}\text { Number of } \\
\text { passes }\end{array}$ & $\begin{array}{c}\text { Variation of heat input } \\
(\mathbf{k J} / \mathbf{m m})\end{array}$ & $\begin{array}{c}\text { Heat input per pass average } \\
(\mathbf{k J} / \mathbf{m m})\end{array}$ & $\begin{array}{c}\text { Welding speed } \\
(\mathbf{m m} / \mathbf{s})\end{array}$ & $\begin{array}{c}\text { Time of welding } \\
(\mathbf{s})\end{array}$ \\
\hline $\mathrm{G}-5\left(35^{\circ}\right)$ & 12 & $0.45-0.90$ & 0.60 & 4.31 & 770.0 \\
$\mathrm{G}-6\left(35^{\circ}\right)$ & 14 & $0.60-1.06$ & 0.63 & 4.74 & 740.0 \\
$\mathrm{G}-7\left(25^{\circ}\right)$ & 10 & $0.44-0.90$ & 0.53 & 4.90 & 565.0 \\
$\mathrm{G}-8\left(25^{\circ}\right)$ & 10 & $0.54-1.18$ & 0.68 & 4.61 & 505.0 \\
\hline
\end{tabular}


obtainment of acicular ferrite in a massive form in weld metal is only possible in superior cooling conditions.

The microestrutural characterization was also performed on an enlarged scale. For a better identification of the microconstituents, analyses were carried out by Scanning Electron Microscopy (SEM). The fusion zone of the G-7 and G-8 are shown in Figures 6 and 7.

Figures 6 presents perlite $(\mathrm{P})$ and constituents martensiteaustenite (M-A) in a ferrite matrix. In Figure 7 (G-8) it is perceived some islands of retained austenite (AR), the M-A constituent and a grain which contours have a small presence of acicular constituent (FA) in the central region. Previous studies explain origin and effects of the microconstituents in welded joint (Aquino Filho ${ }^{16}$ ).

The macrographs shown in Figures 8 and 9 are particularly related to conditions G-6 and G-8, with bezel

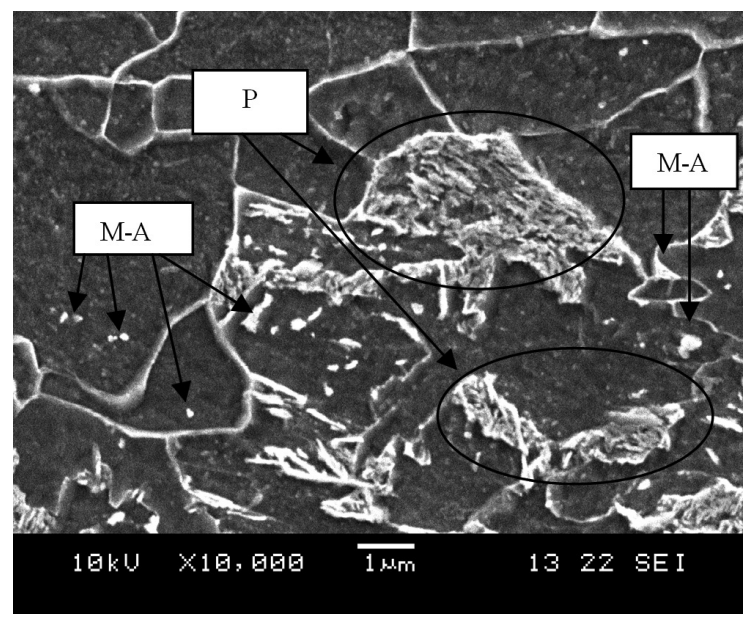

Figure 6. Fusion zone, G-5, showing $\mathrm{H}-\mathrm{E}$ and $\mathrm{M}-\mathrm{A}$ constituents.

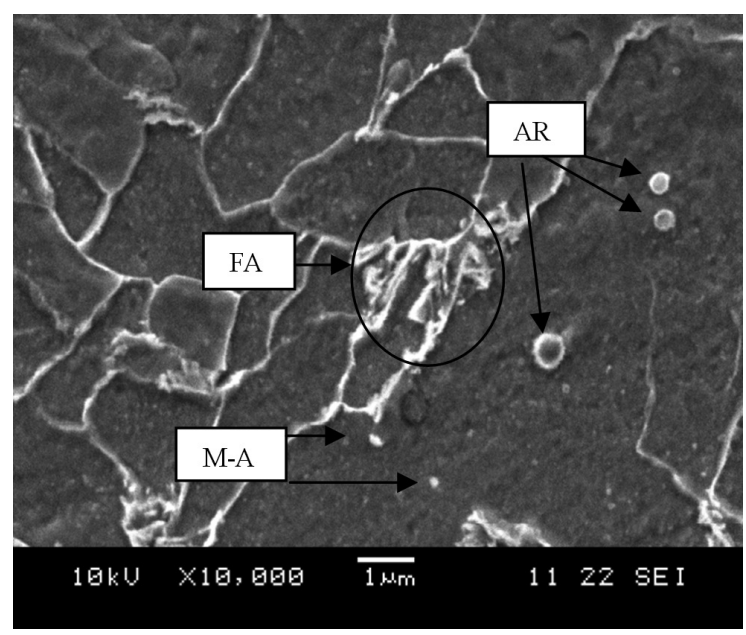

Figure 7. Fusion zone, G-8, showing AR, FA, and M-A constituents. of $35^{\circ}$ and $25^{\circ}$. Although they present different geometries, these two joints have approximately the same width of HAZ: $2.2 \mathrm{~mm}$ for G-6 and $2.1 \mathrm{~mm}$ for G-8. The other HAZs extent measurements were $2.0 \mathrm{~mm}$ for G-5 and $1.8 \mathrm{~mm}$ for G-7, as shown in Table 7. Taking into account the heat input in relation to HAZ it can be said that for higher heat input greater is the width of HAZ. This suggests the HAZ width depends only on heat inputs values provided in each pass. These macrographs of Figures 8 and 9 also demonstrate the lowest consumption of consumables with $25^{\circ}$ bezel angle.

\subsection{Uniaxial tensile test}

For the mechanical properties analysis, the samples were extracted from the welded test plates under different conditions. After prepared, the samples were submitted to uniaxial tensile tests which results are exposed in Table 8.

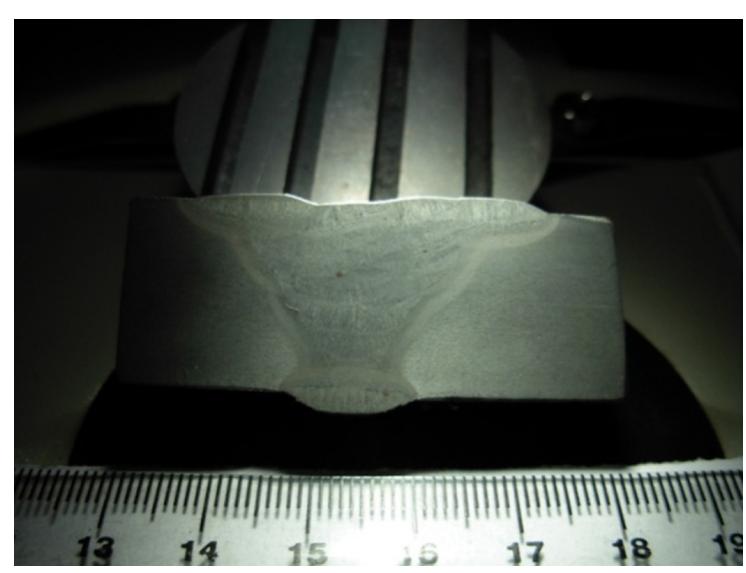

Figure 8. Macrography condition G-6.

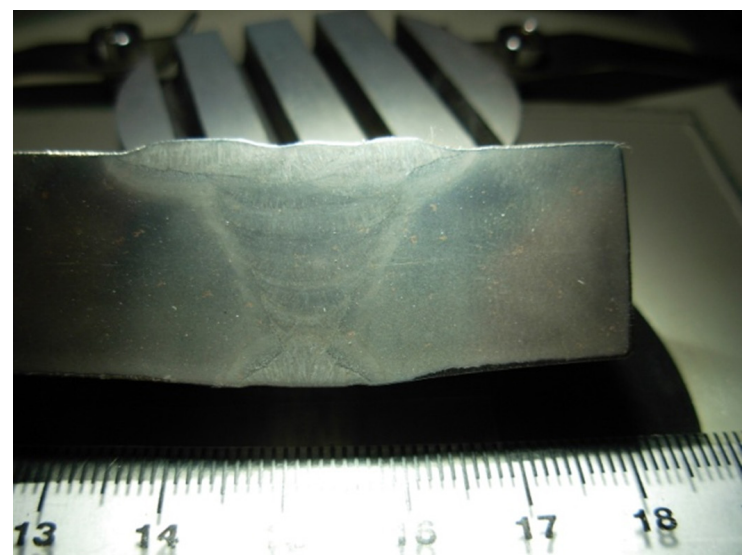

Figure 9. Macrography condition G-8.

Table 7. Comparison between HAZs extension and heat input averages.

\begin{tabular}{lcccc}
\hline \multicolumn{1}{c}{ Weld condition } & $\mathbf{G - 5}\left(\mathbf{3 5}^{\circ}\right)$ & $\left.\mathbf{G - 6}^{\circ} \mathbf{3 5}^{\circ}\right)$ & $\mathbf{G - 7}\left(\mathbf{2 5}^{\circ}\right)$ & $\left.\mathbf{G - 8}^{\circ} \mathbf{2 5}\right)$ \\
\hline HAZ width $(\mathrm{mm})$ & 2.0 & 2.2 & 1.8 & 2.1 \\
Average heat input $(\mathrm{kJ} / \mathrm{mm})$ & 0.60 & 0.63 & 0.53 & 0.68 \\
\hline
\end{tabular}


According to API 5L ${ }^{[11]}$, API 5L X80 steel has a yield strength of $550 \mathrm{MPa}$ and tensile strength of $620 \mathrm{MPa}$. For consumables, the values of mechanical properties, given by A5.29[13], were presented in Table 4.

The rupture of all specimens in the weld can be explained by the fact that tensile strength values were lower than base metal values. Based on the ASME IX ${ }^{[14]}$ standard, which analyzes only the joint tensile strength, all procedures could be considered qualified regarding the tensile tests, however, their elongations are slightly smaller than the standards AWS A5.29[13]. In these results, it was also observed that the specimen with lowest bevel angle $\left(25^{\circ}\right.$ bevel) showed higher resistance in the welded joint.

\subsection{Bending tests}

For each welding condition, some bending guided tests were carried out under the positions: transverse of root, transverse of face and lateral (Table 9). In these tests, the ASME - IX ${ }^{[14]}$ standard states that the bending specimen should not have discontinuities opened in deposited metal or HAZ exceeding $3.2 \mathrm{~mm}$, measured in any direction on the convex surface of the specimen after bending.

Despite some samples have presented non-conformities in the bending tests of face and root, it must be considered that the bending predicted by ASME - IX ${ }^{[15]}$ standard, for a plate thickness of $19 \mathrm{~mm}$ is only necessary the lateral bending. According to this, all conditions are in agreement with the procedures and could be considered as qualified for bending tests.

\subsection{Microhardness test}

It can be seen in Table 10 the tendency of a larger hardness variation if there is a bigger heat input, because of the bigger granulation (Figures 2 and 3).

The microhardness presented a lower hardness in the weld center, increasing gradually towards the HAZ and stabilizing in the base metal, Figures 10 and 11. It can be justified by the lowest mechanical resistance of the welded metal, according to Table 8 results.

\subsection{Charpy impact test}

The Charpy impact test was performed on specimens at temperatures of $0^{\circ} \mathrm{C}$ and $25^{\circ} \mathrm{C}$ (ambient) and their results are displayed in Table 11.

The results of Table 11 can be justified by the location of test specimen notch. As can be seen in Figure 2, the notch is located in many zones of the welded joint. It also occurs with the weld metal, Figure 3. In a certain way, this results show that the highest heat input contributed to a higher growth of grains in the weld metal, reducing the joint resistance.

Table 8. Results of tensile tests.

\begin{tabular}{|c|c|c|c|c|}
\hline SWP test specimen & $\begin{array}{c}\text { Yield Strength } \\
(\mathrm{MPa})\end{array}$ & $\begin{array}{c}\text { Tensile Strength } \\
\text { (MPa) }\end{array}$ & $\begin{array}{c}\text { Elongation } \\
(\%)\end{array}$ & Region of the rupture \\
\hline $\mathrm{G} 5.1\left(35^{\circ}\right)$ & 550.00 & 638.36 & 22.77 & Broke in the welding \\
\hline $\mathrm{G} 5.2\left(35^{\circ}\right)$ & 570.00 & 628.78 & 21.84 & Broke in the welding \\
\hline $\mathrm{G} 6.1\left(35^{\circ}\right)$ & 520.00 & 574.61 & 19.69 & Broke in the welding \\
\hline $\mathrm{G} 6.2\left(35^{\circ}\right)$ & 480.00 & 566.56 & 18.85 & Broke in the welding \\
\hline $\mathrm{G} 7.1\left(25^{\circ}\right)$ & 650.00 & 692.82 & 19.21 & Broke in the welding \\
\hline G $7.2\left(25^{\circ}\right)$ & 630.00 & 678.48 & 20.85 & Broke in the welding \\
\hline $\mathrm{G} 8.1\left(25^{\circ}\right)$ & 600.00 & 626.69 & 17.90 & Broke in the welding \\
\hline $\mathrm{G} 8.2\left(25^{\circ}\right)$ & 580.00 & 614.82 & 18.75 & Broke in the welding \\
\hline
\end{tabular}

Table 9. Results of Bending Test Conditions.

\begin{tabular}{cccc}
\hline Weld condition & Root bending & Face bending & Lateral bending \\
\hline G-5 $\left(35^{\circ}\right)$ & Rupture in BM & Rupture in WM & Good for all specimens \\
G-6 $\left(35^{\circ}\right)$ & Rupture in BM & Rupture in WM & Good for all specimens \\
G-7 $\left(25^{\circ}\right)$ & Rupture in BM & Rupture in BM & Good for all specimens \\
G-8 $\left(25^{\circ}\right)$ & Rupture in BM & Rupture in BM & Good for all specimens \\
\hline
\end{tabular}

Table 10. Mean values of conditions microhardness.

\begin{tabular}{|c|c|c|c|}
\hline \multicolumn{4}{|c|}{ Variation of microhardness (HV) } \\
\hline G-5 Condition (Region) & G-6 Condition (Region) & G-7 Condition (Region) & G-8 Condition (Region) \\
\hline $202.88(\mathrm{FZ})-247.19(\mathrm{BM})$ & 191.96(FZ) - 263.54(BM) & $217.41(\mathrm{FZ})-249.45(\mathrm{MB})$ & 191.17(FZ) - 264.49(BM) \\
\hline 45.31 & 71.58 & 32.04 & 73.32 \\
\hline \multicolumn{4}{|c|}{ Average heat input (kJ/mm) } \\
\hline 0.60 & 0.63 & 0.53 & 0.68 \\
\hline
\end{tabular}




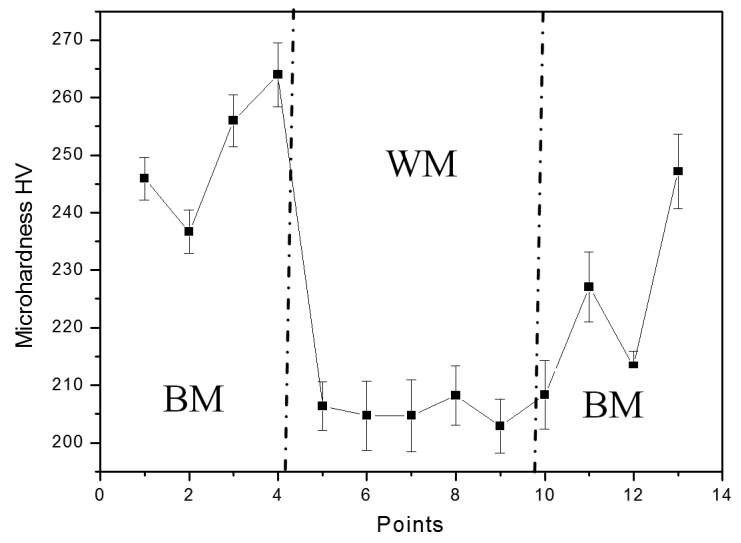

Figure 10. Microhardness profile of the condition G-5.

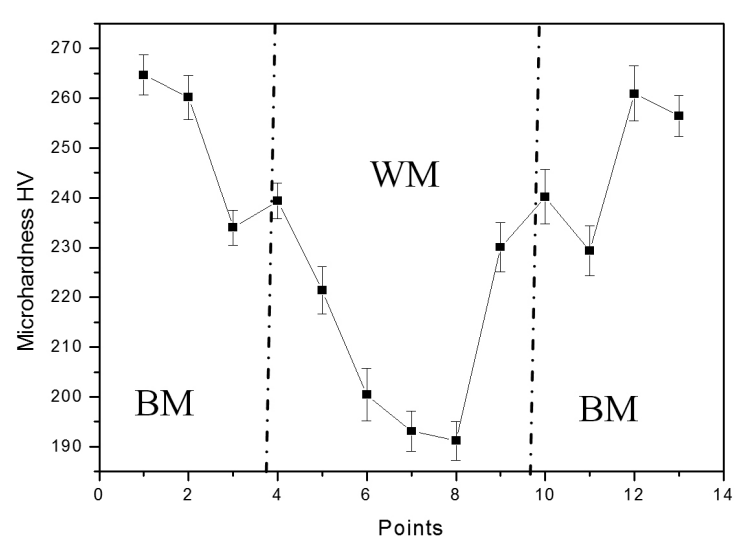

Figure 11. Microhardness profile of the condition G-8.

Table 11. Average values of the Charpy V impact tests.

\begin{tabular}{|c|c|c|c|c|c|}
\hline \multirow[t]{2}{*}{ Weld condition } & \multirow{2}{*}{$\begin{array}{l}\text { Average heat input } \\
(\mathrm{kJ} / \mathbf{m m})\end{array}$} & \multicolumn{4}{|c|}{ Average Energy (J) } \\
\hline & & $\begin{array}{l}\text { Welding metal } \\
\qquad\left(25^{\circ} \mathrm{C}\right)\end{array}$ & $\begin{array}{l}\text { Welding metal } \\
\qquad\left(0^{\circ} \mathrm{C}\right)\end{array}$ & $\begin{array}{c}\text { HAZ } \\
\left(25^{\circ} \mathrm{C}\right)\end{array}$ & $\begin{array}{l}\text { HAZ } \\
\left(0^{\circ} \mathbf{C}\right)\end{array}$ \\
\hline G-5 & 0.60 & $102.00 \pm 11.21$ & $107.00 \pm 9.87$ & $224.00 \pm 21.35$ & $78.80 \pm 8.54$ \\
\hline G-6 & 0.63 & $149.00 \pm 20.11$ & $58.00 \pm 5.32$ & $185.00 \pm 16.33$ & $92.60 \pm 10.68$ \\
\hline G-7 & 0.53 & $158.00 \pm 22.13$ & $102.00 \pm 8.63$ & $151.00 \pm 12.47$ & $132.70 \pm 12.87$ \\
\hline G-8 & 0.68 & $125.00 \pm 11.68$ & $66.50 \pm 6.12$ & $155.00 \pm 13.28$ & $59.14 \pm 6.86$ \\
\hline
\end{tabular}

\section{Conclusions}

The welding of API 5L X 80 steel can be accomplished with evenmatched (E81T1-Ni1C) consumables. Depending on the pipeline operating conditions, since the welding parameters reproduce the same transfer mode by short circuit, so mechanical properties may be achieved as this study shows.

The conditions that showed higher hardness variation and smaller impact resistance level are justified by the higher average heat input.

The rupture of all specimens in the weld metal in the tension tests is explained by the values of the resistance limit of the base metal being higher than the weld metal. The lateral bending tests haven`t presented measurable discontinuity. Those results follow the AWS A5.29 ${ }^{[13]}$ and ASME IX ${ }^{[14]}$ standards.

\section{References}

1. Hillenbrand HG, Niederhoff KA, Hauck G, Perteneder EE and Wellnitz G. Procedures, considerations for welding x 80 line pipe established. Oil and Gas Journal. 1997; 95(37):2-7.

2. Quintana MA and Johnson MQ. The Effects of Intermixed Weld Metal on Mechanical Properties - Part 1: Dilution from FCAW-S Weld Metal Influences SMAW Mechanical Properties. In: Procedings of the AWS Anual Meeting; 1997. Welding Research Supplement. 1999; 87-99.

3. American Welding Society - AWS. D1.1: Structural Welding Code-Steel. AWS; 1995.
The microstructural analysis by optical microscopy revealed a tendency of producing acicular microconstituents in the weld metal although polygonal ferrite still is predominant in the microstructure. This result suggests that the obtainment of acicular ferrite in a massive form in weld metal is only possible in superior cooling conditions. The analysis accomplished by scanning electron microscopy showed in every condition the microconstituents M-A, the retained austenite and the acicular ferrite traces in weld metal.

\section{Acknowledgements}

We would like to thank Tenaris Confab Company for supplying the API 51 X80 pipeline steel, as well as to White Martins SA for supplying the consumable (wire and gas), Codistil Dedine do Nordeste and SENAI of Cabo de Santo Agostinho for the welding.

4. Graf MK and Niedorhoff KA. Overmatching Criterion and Manual Welding of Line Pipe in Grades ${ }^{3}$ X 70 . Pipeline Technology. 1995; 1:1-18. Proc. Pipeline Technology Conference Ostend, Belgium. p. 11-14.

5. Loureiro AJR. Effect of Heat Input on Plastic Deformation of Undermatched Welds. Journal of Materials Processing Techonology. 2002; 128:240-249. http://dx.doi.org/10.1016/ S0924-0136(02)00457-0

6. Loureiro AJR and Fernandes AA. Toughness of CG HAZs of Welds in Q and T Steels. Welding Journal. 1994; 73(11):225s-32s.

7. Toyoda M, Thaulow JG and Blauel JG. Strength Mismatching and its Influence on the Performance of Welded Structures, 
Mismatching of Welds, ESIS 17. London: Mec. Eng. Publ; 1994. p. 335-350.

8. Utterberg B and Svensson LE. Effect of Normalizing Heat Treatment on Microstructure and Properties of Nickel Alloyed C-Mn Weld Metals. Science and Technology of Welding and Joining. 2002; 7(6):363-373. http://dx.doi. org/10.1179/136217102225006877

9. Evans GM. The Effect of Nickel on the Microstructure and Proprieties of C-Mn All-Weld Metal Deposits. Welding Research Abroad. 1991; 27(2).

10. Vieira LA. Avaliação da Tenacidade Após Tratamento Térmico de Alívio de Tensões em Soldas Produzidas com Armes Tubulares Rutílicos que Contenham Níquel. [Dissertação]. Belo Horizonte: Escola de Engenharia, Universidade Federal de Minas Gerais; 2006.

11. American Petroleum Institute - API. API 5L: Specification for Line Pipe. 42nd ed. Washington; 2007.
12. American Society for Testing and Materials - ASTM. A 370: Standard Test Method and Definitions for Mechanical Testing of Steel Products. ASTM; 2005.

13. American Welding Society - AWS. AWS A5.29: Specification for Low Alloy Electrodes For Flux Cored Arc Welding. AWS; 2007.

14. American Society of Mechanical Engineers - ASME. IX: Qualification Standard for Welding and Brazing Procedures, Welders, Brazers, and Welding and Brazing Operators. ASME; 2007.

15. American Society for Testing and Materials - ASTM. E 384: Standard Test Method for Microindentation Hardness of Materials. ASTM; 2005.

16. Aquino $\mathrm{A} \mathrm{F}^{\circ}$. Estudo do Comportamento Mecânico de Juntas de Aço API 5 L X80 Soldadas com Arames Tubulares "Undermatched e Evenmateched". [Tese]. Recife: Universidade Federal de Pernambuco; 2011. 